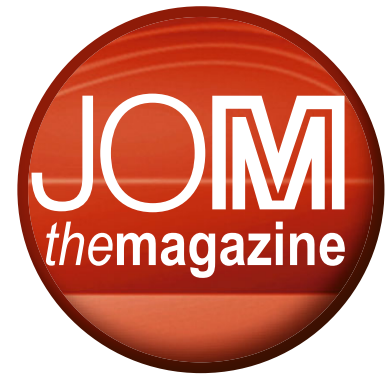

\section{TMS Board of Directors}

David H. DeYoung

President

Director, Research

and Development,

Alcoa

\section{Stanley M. Howard \\ Past President \\ Professor Emeritus, \\ South Dakota School of \\ Mines \& Technology}

Kevin J. Hemker

Vice President

Alonzo G. Decker Chair in

Mechanical Engineering,

Johns Hopkins University

Joy H. Forsmark

Financial Planning Officer

Technical Expert,

Light Cast Metals,

Ford Motor Company

Amy J. Clarke

Director, Membership \&

Student Development

Associate Professor,

Colorado School of Mines

Michele V. Manuel

Director, Content

Development \&

Dissemination

Professor,

University of Florida

\section{Alan A. Luo \\ Director/Chair \\ Light Metals Division \\ Professor and Director, \\ Light Metals and \\ Manufacturing \\ Research Laboratory, \\ The Ohio State University}

\title{
New TMS Board Members Draw on Past Experiences as They Look Ahead
}

\author{
Kelly Zappas
}

\section{TMS board motions, minutes, and musings}

This regular JOM feature offers news and perspectives on TMS governance, as well as Board of Directors activities, priorities, and decisions. To find out how you can become involved in these initiatives, contact James J. Robinson, TMS Executive Director, at robinson@ @tms.org.

Here is a quick quiz for you: What do the newly confirmed members of the TMS Board of Directors all have in common? There are the obvious things, like an interest in minerals, metals, and materials science and engineering and a desire to contribute to the future of TMS. But less obviously, all four started their affiliation with TMS in their student years and have remained a part of the Society ever since. At the TMS 2018 Annual Meeting \& Exhibition (TMS2018) in March, these incoming TMS board members will begin or continue their terms. Take a few minutes to meet these active TMS members, learn how TMS has influenced their careers, and gain insight on what they hope to accomplish during their time in office.

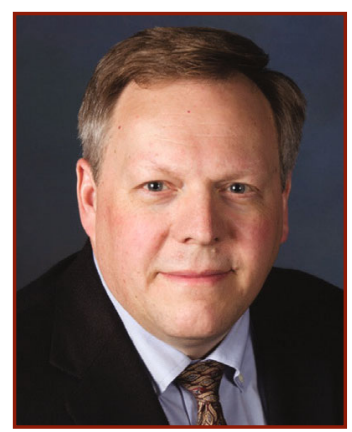

\section{James C. Foley, 2018 TMS Vice President \\ "Every position I have accepted in my professional career is} somehow related to the network of friends and colleagues I have developed through my involvement in TMS," said James Foley, scientist at Los Alamos National Laboratory (LANL).

Foley will begin the three-year TMS Presidential Rotation when he is installed as the Society's Vice President at TMS2018. He will lead the TMS Board of Directors as the 2019 TMS President before moving to the role of Past President in 2020 .

Foley joined TMS as an undergraduate student, encouraged by his M.S. and Ph.D. advisor John H. Perepezko at the University of Wisconsin-Madison. Following graduation, Foley received guidance from Dan Thoma, 2003 TMS President, as well as John Smugeresky and other TMS members on how he could best help the Society. He completed his post doctoral work at Ames Laboratory, where he collaborated with a number of prominent TMS members, including past TMS presidents J. Wayne Jones (1999), John E. Allison (2002), and Brajendra Mishra (2006).

"My move to LANL would not have been possible without the interactions with the many LANL TMS members at TMS conferences," said Foley. "On top of that, my involvement has enabled me to interact with people outside my area of expertise that I would not have otherwise been exposed to. What has kept me active in TMS is other members' encouragement of my service to the Society and seeing the difference you can make by working together with others."

In his time as a TMS volunteer, Foley has served twice on the TMS Board of Directors, first as Programming Director/ Chair (2006-2009) and then the Materials Processing \& Manufacturing Division (MPMD) Director/Chair (2013-2016). He has also served as the Programming Coordinating Committee chair for the Materials Science \& Technology (MS\&T) meeting and exhibition. He was the recipient of the 2017 TMS Alexander Scott Distinguished Service Award in recognition of his many contributions to TMS.

Foley believes his experience with TMS programming, MS\&T, and TMS division leadership, along with his term on the 
ASM International Board of Trustees, has positioned him well to provide historical perspective to the board.

"Each one of the TMS board members brings a wealth of knowledge and experience that are different than mine," said Foley. "I gain by hearing and understanding their perspectives. I personally hope to contribute by encouraging other members to become more involved, either through filling positions, nominating worthy people for awards, and promoting TMS activities. My checklist during my term of office is to volunteer my time, donate to the TMS Foundation, nominate people, promote TMS, and encourage others to do the same."

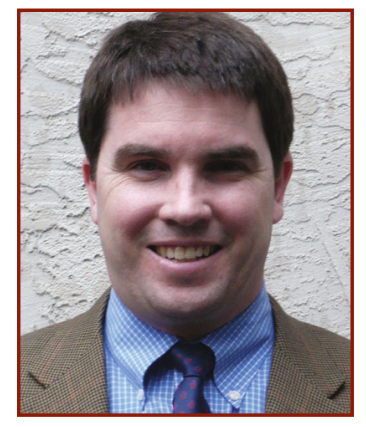

\section{Adrian C. Deneys, Financial Planning Officer}

While Adrian Deneys first joined TMS as a student at the University

of Missouri-Rolla (now the Missouri University of Science and Technology), it was his company, Praxair Inc., that asked him to get involved in the society after graduation to expand the organization's understanding of non-ferrous metallurgical industries. Deneys, currently Praxair's Business Development Manager, joined the TMS Pyrometallurgy Committee, volunteered to serve as vice chair, and eventually chaired that committee. He was the recipient of the 2001 Extraction \& Processing Division (EPD) Young Leaders Professional Development Award in recognition of his early promise as a future leader in the Society. After serving as EPD Programming Representative, he was elected to serve as EPD Board Director/ Chair from 2011 to 2014, and received the EPD Distinguished Service Award in 2015.

"Participating in TMS activities broadened my exposure to new and existing process technologies for light metals and base (or non-ferrous) metals areas, from extraction and processing to end uses," said Deneys. "Many Praxair customers are represented at TMS.
Involvement at TMS opened the door to opportunities to meet persons from companies, universities, and laboratories. This exposure helped me to learn more about those companies, and the processes they use, which informs my work for Praxair."

In March 2018, Deneys will take on the role of Financial Planning Officer for TMS, making him one of the four volunteer members to serve as executive officers of the Society (along with the President, Vice President, and Past President).

"I look forward to implementing the TMS financial strategic plan and to learning from fellow committee and board members," said Deneys. "I hope to contribute to the Society's long-term financial strength."

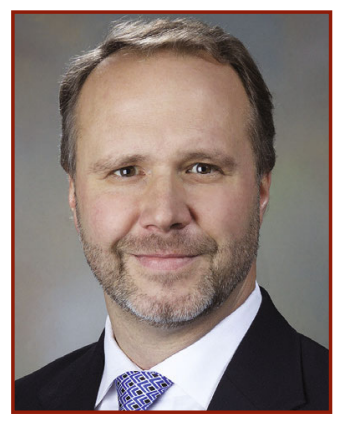

Brad L.
Boyce,
Programming
Director/
Chair

\section{"I first} attended a TMS conference as a graduate student, and keep coming back," said Brad Boyce, distinguished member of the technical staff at Sandia National Laboratories. As the incoming TMS Programming Director/Chair, he recognizes the central role that technical programming plays in the Society and the role that he can play in strengthening that aspect of TMS.

"At its core, TMS arranges for a literal meeting-of-the-minds, where scientists and engineers across the globe can share their most exciting new results, learn from each other's knowledge, and catalyze ideas for the future," he said. "The grassroots nature of TMS symposium organization encourages new ideas and volunteerism. I want to facilitate that enabling spirit, while providing a meeting that is thoughtfully structured so that members and participants can maximize positive outcomes."

On a more personal note, Boyce says that TMS has expanded his professional family far beyond the reaches of his employer. Through such experiences as
TMS Board of Directors

Chester Van Tyne

Director, Professional Development

FIERF Professor,

Colorado School of Mines

Corbett C. Battaile

Director/Chair

Materials Processing \&

Manufacturing Division

Principal Member of

Technical Staff, Sandia

National Laboratory

John Howarter

Director, Public \&

Governmental Affairs

Assistant Professor,

Purdue University

Ellen K. Cerreta

Director/Chair

Structural Materials

Division

Group Leader,

Los Alamos National Laboratory

Srinivas Chada

Director, Programming

Senior Principal Engineer, Stryker

Raymundo Arroyave

Director/Chair

Functional Materials

Division

Associate Professor, Texas A\&M University

Cynthia Belt

Director/Chair

Extraction \& Processing

Division

Metals Energy

Management LLC

James J. Robinson

Secretary

TMS Executive Director 
receiving the 2009 Structural Materials Division Young Leaders Professional Development Award, Boyce notes that TMS has connected him to both experienced veterans and rising stars in the field.

"I am looking forward to hearing the diverse thoughts on how to strengthen our Society," said Boyce. "Each division has its own character, and it is fascinating to integrate these ideas and personalities in a way that advances the Society and the field. Personally, I hope that new TMS programming initiatives, some of which are already underway, create meetings that are even more enjoyable and energizing. Whether it's expanding poster sessions or adopting discussion panels, I hope that these additional chances for networking and idea sharing enhance the value proposition for our participants."

\section{Are You the Next Member of the TMS Board of Directors?}

TMS is accepting nominations for two Board of Directors positions for the 2019-2022 term until January 16, 2018. The open positions are the Presidential Rotation and Membership and Student Development Director.

The Presidential Rotation encompasses three successive one-year positions: Vice President, President, and Past President. All three roles are officer positions within the Society and carry unique responsibilities The role of President includes serving as chair of the Board of Directors.

The Membership and Student Development Director represents the entire membership in carrying out the professional activities of the Society concerned with its professional and student membership-related activities, including recruitment and retention, diversity and inclusion initiatives, and other issues consistent with the Society's strategic plan.

Packages for applicants to these positions will be considered by the Society's Nominating Committee, which will then recommend a candidate for each position to the Board of Directors.

If approved by the Board of Directors, these endorsed candidates will be presented to the general membership for approval by July 2018.

To access complete job descriptions and qualifications for each office, as well as the Nominee Statement Form and nomination instructions, visit the TMS website at www.tms.org and log on to the Access Member

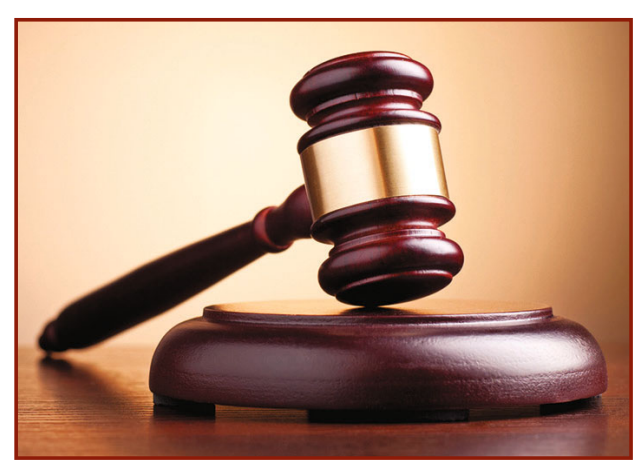

Benefits section (found under the Membership tab in the main menu). From there, you will be able to navigate to the Submit Board Nominations page. For additional information, contact James J. Robinson, TMS Executive Director, at robinson@tms.org.

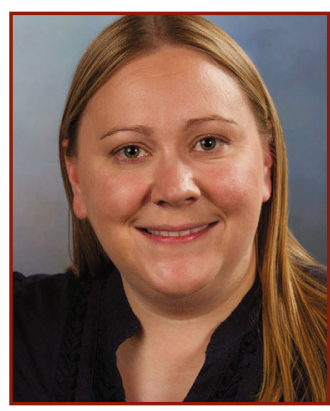

Amy Clarke, Membership and Student Development Director/Chair

"TMS has not only opened up my professional network, it built it," said Amy Clarke, an associate professor at the Colorado School of Mines, whose involvement with TMS goes back to her days as an undergraduate student in an early version of the Material Advantage student membership program.

Clarke joined the TMS Phase

Transformations and Young Professionals Committees as a postdoctoral researcher and was the recipient of several TMS awards devoted to providing early career professionals with leadership development opportunities. These include the 2008 MPMD Young Leaders Professional Development Award, the 2010 TMS/ Japan Institute of Metals Young Leaders International Scholar Award, and the 2013 TMS/Federation of European Materials Societies Young Leaders International Scholar Award.

"I have had the opportunity to contribute to technical programming and administrative functions in numerous ways," said Clarke. "In particular, as a young professional, TMS gave me many chances to develop and build a foundation of leadership skills that continues to support my career development."

She has already served a three-year term on the TMS Board of Directors as Membership and Student Development Director and was recently confirmed to serve a fourth year in this position, lending her some perspective on what to expect in the coming year.

"TMS is working hard to promote diversity and inclusion in the Society," said Clarke. "It begins with membership and student development and our ability to recruit and retain existing and future members by being a welcoming society to everyone. It is rewarding to see that diversity increases at younger age demographics, suggesting a positive trend. I hope to see diversity and inclusion become increasingly intrinsic to everything we do in TMS." 